\title{
NOTA PRELIMINAR SÔBRE A DISTRIBUIÇĀO DO RADIOZINCO NO TOMATEIRO
}

\author{
E. MALAVOLTA (*) \\ A. B. CARLTON (**)
}

Este trabalho é parte de um estudo sistemático, destinado a determinar o periodo de exposição mais adequado para a obtenção de radioautógrafos quando o isótopo radioativo emite principalmente radiações gama. Como, no curso da investigação, surgiram alguns resultados interessantes, esta nota é agora publicada.

Seedlings de tomate com 2 semanas de idade, foram transferidos para vasilhas Pyrex de 21 de capacidade contendo uma solução que era $0.001 \mathrm{M} \mathrm{KH} 2 \mathrm{PO}, \quad 0.005 \mathrm{M} \mathrm{KNO3,} 0.005 \mathrm{M}$ $\mathrm{Ca}(\mathrm{NO}) 2$ e $0.002 \mathrm{M}$ MgSO4 suplementada com $0.5 \mathrm{ppm} \mathrm{B,} 0.5$ ppm Mn, 0.05 ppm Zn, 0.02 ppm Cu e 0.01 ppm Mo (HOAGLAND

(*) Secção Técnica "Química Agrícola", E. S. A. "Luiz de Queiroz", U.S.P.

(**) Dept. of Plant Nutrion, Univ. of California, Berkeley, Calif., U.S.A. 
and ARNON, 1950). O ferro foi adicionado como versenato (JACOBSON, 1950). As soluções eram renovadas semanalmente permanecendo sob aeração contínua. As plantas foram cultivadas assim durante 4 semanas. Nesse período forneceu-se um total de 0.5 microcurie de $\mathrm{Zn} 65$ para um grupo de 4 plantas. C diozinco foi usado na forma de $\mathrm{Zn} 65 \mathrm{Cl} 2 \mathrm{em} 0.1 \mathrm{~N} \mathrm{HCl}$. O material radioativo foi produzido por bombardeamento do cobre com deuterons no ciclotron de 60 polegadas em Berkeley.

A técnica usada para a obtenção dos radioautógrafos foi a de ARNON et al. (1940), com ligeiras modificações. O material foi colhido ràpidamente e logo a seguir montado à temperatura ambiente; foi depois para uma câmara a $5^{\circ} \mathrm{C}$. na qual permaneceu durante o tempo de exposição; o efeito da baixa temperatura seria o de evitar uma possível redistribuição do Zn65 no material após a colheita. Algumas horas antes da manipulação, colheu-se um foliolo cuja área e atividade foram medidas. Fixou-se, como ponto de partida 106 contagens $/ \mathrm{cm} 2$. $\mathrm{Da}$ atividade encontrada calculou-se que o tempo de exposição necessário seria 4 dias. O primeiro radicautógrafo (Fig. 1) foi feito na quarta semana de cultivo, $24 \mathrm{hrs}$. depois da adição semanal de $\mathrm{Zn65Cl2}$; o segundo (Fig.2) na mesma semana porém 4 dias após a adição mencionada.

Nas folhas do primeiro radioautógrafo nota-se uma acentuada acumulação do radiozinco nas veias e em pontos de inserção dos folíolos; há também alguma acumulação nas pontas dos folíolos o que indicaria, talvez, gutação; a secção de caule é fortemente radioativa especialmente na casca e na medula. No segundo radioautógrafo vê-se outra vez a acumulação na casca e na seç̧ão transversal, pequenos pontos brancos marcam a situação dos vasos do floema. Os folíolos do segundo radioautografo mostram, entretanto um padrão de distribuição completamente diverso. A atividade nas veias é proporcionalmente bem menor, o material estando mais ou menos uniformemente distribuido nos espaços internervais, concentrando-se parcialmente na periferia.

Encontra-se geralmente na literatura afirmações de que certos elementos se acumulam nas veias (BIDDULPH, 1951) enquanto outros se acumulam nos espaços entre as nervuras (STOUT and MEAGHER, 1948). Entretanto a presente nota mostra como a forma de distribuição pode ser afetada. A finalidade desta publicação é então por em relevo a importância do fator tempo e da técnica de amostragem quando se estuda a distribuição de nutrientes com auxílio de radioautógrafia. 


\section{Note on the distribution of radiozinc in the tomato plant}

This work is part of a systematic study designed to ascertain the most suitable number of counts per square centimeter required to take plant radioautographs when the element used is mainly a gamma emitter. Since in the course of the investigation some interesting results appeared, this note is now being submitted.

Two-week old tomato seedlings were transferred to 2-liter Pyrex baking dishes containing a solution 0.001 M KH2PO4, $0.005 \mathrm{M}$ KNO3, $0.005 \mathrm{M} \mathrm{Ca}$ (NO3) 2 and $0.002 \mathrm{M}$ MgSO4 suplemented with $0.5 \mathrm{ppm} \mathrm{B}, 0.5 \mathrm{ppm} \mathrm{Mn,} 0.05 \mathrm{ppm} \mathrm{Zn,} 0.02 \mathrm{ppm} \mathrm{Cu}$ and $0.01 \mathrm{ppm}$ Mo (HOAGLAND and ARNON, 1950). Iron was added as the salt ethylenediamine tetraacetic acid (JACOBSON, 1950). The solutions were renewed weekly, and constantly aerated. The plants grew for a period of four weeks. A total of 0.5 microcuries of $\mathrm{Zn} 65$ per group of four plants was supplied in that period. Radiozinc was given as $\mathrm{Zn} 65 \mathrm{Cl} 2$ in $0.1 \mathrm{~N} \mathrm{HCl}$. The radioactive material was obtained from deuteron-bombarded copper from the Berkeley 60 inch cyclotron.

The techique used for obtaining the radioautographs was a slight modification of that described by ARNON et al. (1940). The plant material was quickly harvested and mounted at room temperature and then kept at $-5^{\circ} \mathrm{C}$., during the time of exposure in order to repress a possible redistribution of the radiozinc - a precaution not generally mentioned by the users of the radioautographic technique. $A$ few hours before the harvest, a small leaflet was selected its area measured and the activity counted. It was tentatively fixed as starting point a number of 106 counts $/ \mathrm{cm} 2$ taken at $5 \mathrm{~mm}$ from a 1 " diameter thin mica window G-M tube. From the activity found the time of exposure was calculated to be 4 days. The first radioautograph (Fig. 1) was made in the fourth week after transplanting to the culture, $24 \mathrm{hrs}$. after the weekly addition of $\mathrm{Zn65Cl2}$; the second one (Fig. 2) in the same week, 4 days after the addition of radioactive material.

In the leaves shown in the first radioautograph, a marked accumulation of radiozinc can be seen in the veins as well as in the points of attachment of the leaflets to the rachis; there is also accumulation at almost every leaflet tip, indicating, perhaps, some guttation; the stem section is strongly radioactive especially in the bark and in the pith. In the second radio- 
autograph, again, the concentration of radiozinc in the bark is seen; in the cross section, small dots mark the phloem tissue; these dots correlated with the vertical lines in the strip of bark. The leaves of the second radioautograph show, by contrast a strikingly different pattern of distribution. There is proportionally less activity in the veins, the material being rather uniformly distributed in the interveinal areas. A high accumulation occurred along the edges of the leaflets. At present time no conclusion can be drawn about the possible biological significance of this latter distribution. Besides the small difference in the age of the leaves, the only other difference is the time of sampling with respect to the last addition of $\mathrm{Zn} 65 \mathrm{Cl2}$ to the nutrient solution.

It is generally found in the current literature claims that certain elements accumulate in the veins (BIDDULPH, 1951) whereas others accumulate in the interveinal areas of leaves (STOUT and MEAGHER, 1948). However, the present experiment demonstrates how easily a form of distribution can be affected. The purpose of this note is then to emphasize the importance of the time factor and sampling technique as important points to be considered when conclusions about patterns of distribution of radioelements in leaves are concerned.

\section{LITERATURA CITADA}

ARNON, D. I., STOUT, P. R. and SIPOS, F. 1940. Radioactive phosphorus as indicator of phosphorus absorption of tomato fruits at various stages of development. Amer. Jour. Bot. 27: 791-798.

BIDDULPH, O. 1951. In "Mineral nutrition of plants", pp. 261275, edited by Emil Truog, the University of Wisconsin Press.

HOAGLAND, D. R., and ARNON, D. I. 1950. The water culture method for growing plants without soil. California Agr. Expt. Sta. Circ. 347.

JACOBSON, L. 1950. Maintenance of iron supply in nutrient solutions by a single addition of ferric potassium e thylenediamine tetra-acetate. Plant Physiol. 26: 411-413.

STOUT, P. R. and MEAGHER, W. R. 1948. Studies of the molybdenum nutrition of plants with radioactive molybdenum. Science 108: 471. 


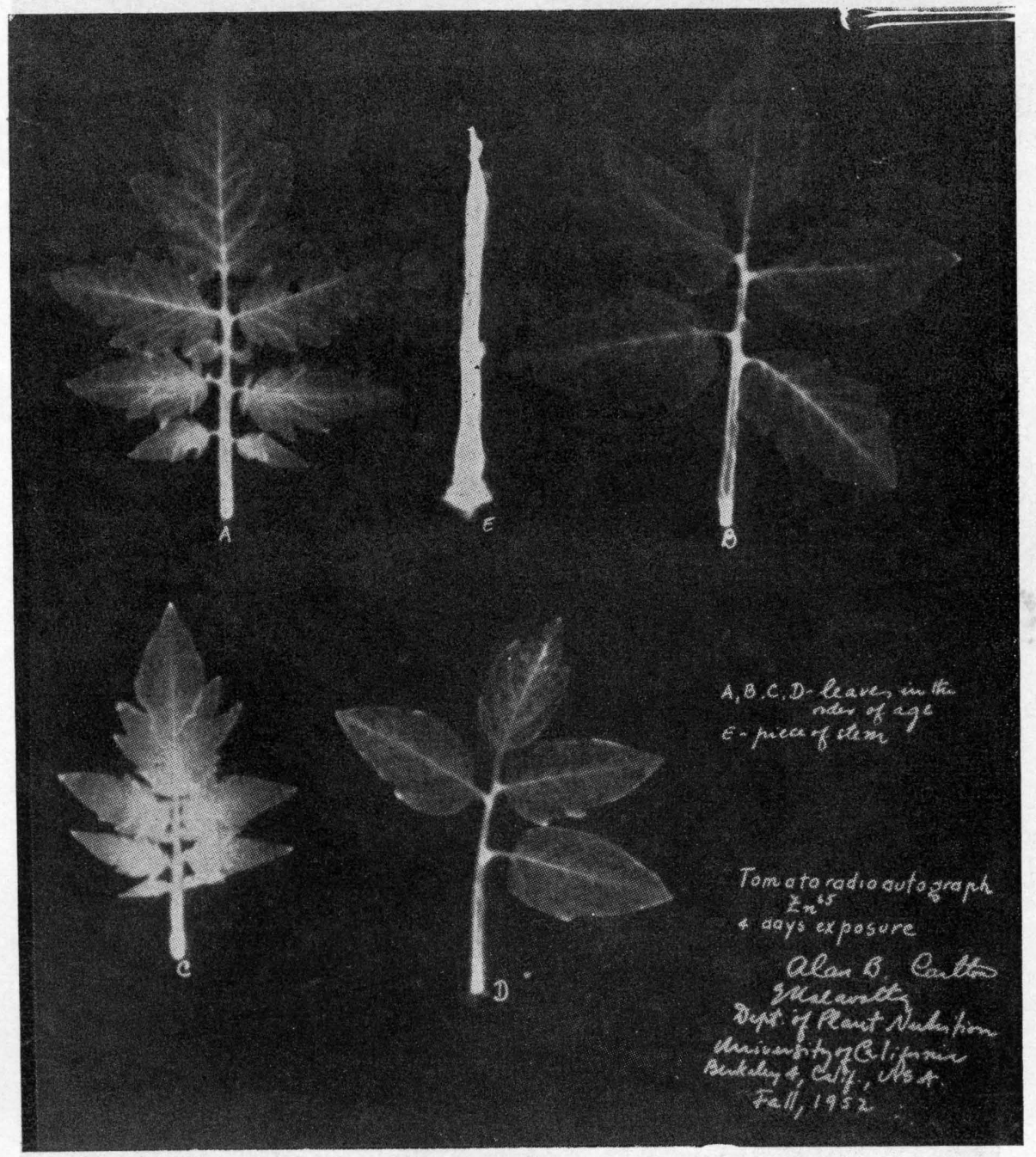

Fig. 1 


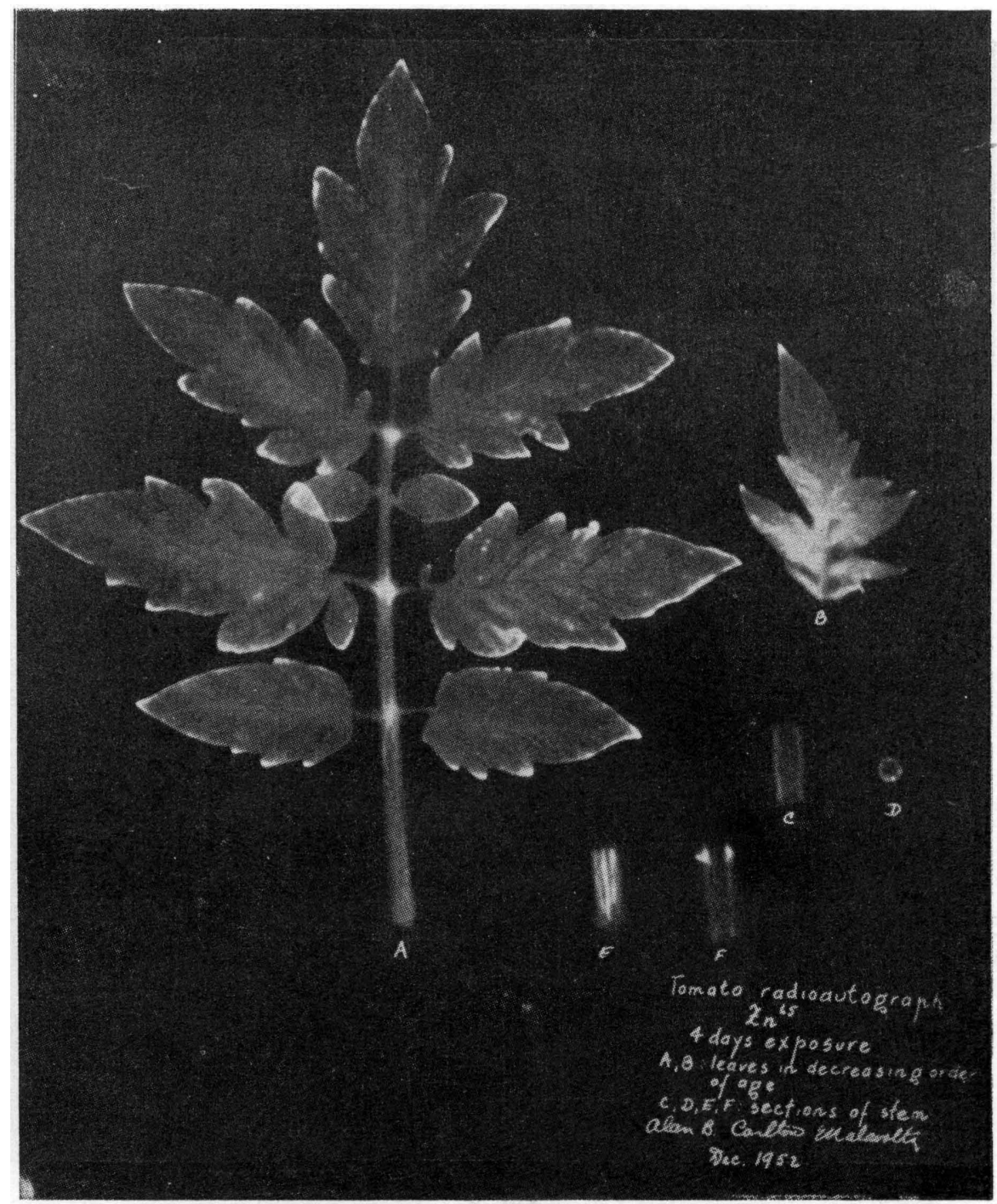

Fio. 2 